\title{
Sequencing Analysis of Myostatin Gene (MSTN) for Meat Cattle in Mongolia
}

\author{
Undarmaa Budragchaa $^{1}$, Munkhtogtokh Baljinnyam², Davaakhuu Luvsan², Sergelen Baldan², Nyamsuren Balsai ${ }^{2}$ \\ and Sodnom Lkhagvasuren ${ }^{3}$ \\ 1. School of Husbandry and Technology, Mongolian University of Life Science (MULS), Zaisan 17024, Ulaanbaatar, Mongolia \\ 2. Research Institute of Animal Husbandry, Mongolian University of Life Science (MULS), Zaisan 17024, Ulaanbaatar, Mongolia \\ 3. Institute of Veterinary Medicine, Mongolian University of Life Science (MULS), Zaisan 17024, Ulaanbaatar, Mongolia
}

\begin{abstract}
In developed countries, study on special or candidate genes, which are useful for identifying species, breed and productivity of livestock, was conducted at high level and the results have already been used in practice. Such advanced technology and innovation that we are facing is necessary to adopt in Mongolia. In this study, the myostatin gene (MSTN) was investigated as a candidate gene for meat animal in Mongolian breeds of cattle. The conventional phenol-chloroform method and FavorPrep ${ }^{\mathrm{TM}}$ tissue DNA extraction kit were used for DNA isolation, and the polymerase chain reaction (PCR) and sequencing analysis were used for further study. The nucleotide sequences of MSTN gene from Selenge, Kazakh white head breeds and Mongolian cattle were sequenced and reported on the DDBJ/EMBL/GenBank database (LC142726, LC146648, LC146649), and Selenge breed showed the result of single nucleotide mutation in MSTN gene.
\end{abstract}

Key words: Meat cattle, candidate gene, myostatin gene, sequencing.

\section{Introduction}

Trend of the world development is directing to effective entrepreneurship by intensifying science technology and innovation, thus developing economy based knowledge. It is crucial to study some special or candidate genes, which are useful for identifying species, breed and productivity of livestock as well as national treasure and wild animals, to determine importance of those genes, introduce world scientific developments to Mongolia by using reliable and highly sensitive modern methods and use those scientific results in animal husbandry, veterinary inspection, forensic veterinary medicine and any other necessity sectors.

Researchers have made first step of explaining potentials of candidate genes, studying their function as expression of beneficial traits and doing genetic manipulation. Determining the genes, which could be

Corresponding author: Sodnom Lkhagvasuren, associate professor, research field: meat science. important for controlling undetected process of change in a certain phenotype and could synthesize certain protein, is the necessary work to be done for science.

A candidate gene approach has been already successfully applied to identify several DNA markers associated with production traits in livestock [1]. The principle is based on the fact that variability within genes coding for protein products involved in key physiological mechanisms and metabolic pathways directly or indirectly involved in determining an economic trait (e.g., feed efficiency, muscle mass accretion, reproduction efficiency, disease resistance) [2] might probably explain a fraction of the genetic variability for the production trait itself. Growth hormone (GH) and myostatin genes (MSTN) play important roles in animal growth, development and muscle mass accretion. For their functions, these two genes can be considered as candidate genes for meat production traits [3].

$M S T N$, known as growth differentiation factor 8 (GDF-8) [4] is a member of the transforming growth 
factor-b (TGF-b) superfamily, which plays an essential role in the regulation of muscle growth and meat quality $[5,6]$. This regulation is via the inhibition of myoblast proliferation and differentiation, specifically in skeletal muscles during embryonic development $[7,8]$.

Some mutations in MSTN gene can inactivate its expression and lead to the non-functional protein, which causes dramatic muscularity and a "double muscling" phenomenon in many species [9, 10].

The first MSTN study using "knockout" (KO) mice showed that the muscle mass was $30 \%$ greater in the KO mice than that in the heterozygous and wild type normal mice [11, 12].

The natural mutations that decrease the amounts of myostatin and/or inhibit its function have been identified in a human subject [13] and several cattle $[14,15]$ and sheep $[16,17]$ breeds. Since the identification of the key role of MSTN in skeletal muscle growth and development, increasing numbers of polymorphisms in MSTN gene have been intensively investigated.

The aim of this research was to investigate and sequence analysis of MSTN gene of Mongolian meat cattle breeds (Selenge cattle, Kazakh white face cattle and Mongolian cattle) by molecular biological methods. The importance of this research is to determine genetic characteristic of MSTN gene in meat cattle breeds, establish gene data bank of cattle breeds and beneficial genes, submit sequences in GenBank, use them for further studies of molecular biology and make a foundation for genetic manipulation.

\section{Materials and Methods}

A total of 30 samples, including 10 from Selenge breed cattle of nucleus herd in Selenge Soum of Bulgan Aimag, 10 from Kazakh white head breed cattle in Khushaat Soum and Enkh-Tal state farm of Selenge Aimag, 10 from Mongolian cattle of Bat's farm of Bayanchandman Soum of Tuv Aimag were collected (Table 1).

\subsection{DNA Isolation}

DNA was extracted from meat and blood samples (Table 1). For each DNA preparation, $1 \mathrm{~g}$ meat was homogenized by mortar and pestle with liquid nitrogen, then transferred to $1.5 \mathrm{~mL}$ tube, added 500 $\mu \mathrm{L}$ of lysis buffer (0.1 M Tris-HCl (pH 8.0), 1\% SDS, $0.1 \mathrm{M} \mathrm{NaCl}, 10 \mathrm{mM}$ EDTA) and gently mixed for 2-3 $\mathrm{h}$ at $55-65{ }^{\circ} \mathrm{C}$. Then samples were treated with proteinase $\mathrm{K}(100 \mu \mathrm{g} / \mathrm{mL})$ for $30 \mathrm{~min}$ at $55-65{ }^{\circ} \mathrm{C}$, added $500 \mu \mathrm{L}$ phenol/chloroform and then centrifuged at $15,000 \times \mathrm{g}$ for $10 \mathrm{~min}$. The supernatant was transferred into new tube. Afterwards 1,000 $\mu \mathrm{L}$ 99\% ethanol and $30 \mu \mathrm{L} 3 \mathrm{M} \mathrm{NaCl}$ were added, incubated $25-30{ }^{\circ} \mathrm{C}$ for $20 \mathrm{~min}$ and then centrifuged at 15,000 $\times \mathrm{g}$ for $15 \mathrm{~min}$ at $4^{\circ} \mathrm{C}$ and discarded the supernatant. Next, $400 \mu \mathrm{L} 70 \%$ ethanol was added into sedment and centrifuged at $15,000 \times \mathrm{g}$ for $5 \mathrm{~min}$ at $4{ }^{\circ} \mathrm{C}$. Again the supernatant was discarded and the DNA extract was dried for 10-15 min in the air. Then dried DNA was dissolved in 25-50 $\mu \mathrm{L}$ of TE buffer (10 mM Tris-HCl (pH 8.0), 1 M EDTA), and the DNA samples were stored at $-20^{\circ} \mathrm{C}$.

Table 1 DNA samples from beef and blood of cattles.

\begin{tabular}{|c|c|c|c|c|c|}
\hline \multirow{2}{*}{ No. } & \multirow{2}{*}{ Breeds } & \multirow{2}{*}{ Origin of animals } & \multicolumn{2}{|c|}{ Number of DNA samples } & \multirow{2}{*}{-Total } \\
\hline & & & From blood & From meat & \\
\hline 1 & Selenge & $\begin{array}{l}\text { Nucleus herd of Selenge breed cattle in Selenge Soum, } \\
\text { Bulgan Aimag }\end{array}$ & 5 & 5 & 10 \\
\hline 2 & Khazakh white head & $\begin{array}{l}\text { Khushaat Soum and Enkh-Tal state farm of Selenge } \\
\text { Aimag }\end{array}$ & 5 & 5 & 10 \\
\hline 3 & Mongol cattle & Bayantsagaan Soum of Tuv Aimag & 5 & 5 & 10 \\
\hline Total & & & 15 & 15 & 30 \\
\hline
\end{tabular}


Common sequences of MSTN gene or the third exon (c960delG) of MSTN gene of three cattle breeds were amplified by use of primers F 5'-CTC CTT GCG GTA GGA GAG TG-3' and R 5'-GGT GCA CAA GAT GGG TAT GAG-3' (Table 1).

\subsection{Polymerase Chain Reaction (PCR) Amplification}

Each PCR amplification reaction was set in a volume of $25 \mu \mathrm{L}$ with approximately $800 \mathrm{ng}$ of template DNA, 10× PCR buffer $2.5 \mu \mathrm{L}$, dNTP $2.0 \mu \mathrm{L}, \mathrm{MgCl}_{2} 2 \mu \mathrm{L}$, each primer $2 \mu \mathrm{L}$ and Taq DNA polymerase $0.5 \mu \mathrm{L}$. PCR amplification was carried out using a thermal cycle as follows: preheating at $95{ }^{\circ} \mathrm{C}$ for $7 \mathrm{~min}, 45$ cycles of $94{ }^{\circ} \mathrm{C}$ for $1 \mathrm{~min}$ (denaturation), $55^{\circ} \mathrm{C}$ for 1 min (elongation), $72{ }^{\circ} \mathrm{C}$ for $45 \mathrm{~s}$ (extension) and a final extension of $72{ }^{\circ} \mathrm{C}$ for $5 \mathrm{~min}$ (Fig. 1). PCR products were analyzed by electrophoresis in $1.5 \%$ agarose gel with ethidium bromide staining.

\subsection{Cloning and Nucleotide Sequencing Analysis}

PCR products was separated by $1.5 \%$ agarose gel electrophoresis and the amplified DNA was purified from the gel by using DNA purification kit (Favorgen Biotech Corp). Purified myostatin DNA was inserted into pGEM-T easy vector (Promega, Madison, WI, USA) and transformed into the JM109 strain of Escherichia coli. Insertion of MSTN in the plasmids was determined by NotI restiction enzyme analysis. The MSTN gene carrying plasmids were purified by the QIAGEN DNA purification kit (QIAGEN, USA). Nucleotide sequence of the MSTN gene was determined by the BigDye Terminator method on an ABI PRISM 3100 automated sequencer (Appield Biosystems, USA).
Sequence alignment and pairwise evaluations of homology were performed using with the GenBank search [18] and NCBI BLAST database [19]. Amino acids translation of the MSTN sequence was determined using MacVector (Oxford molecular, Madison, USA) and GENETYX (Genetyx, Tokyo) softwares.

\section{Results and Discussion}

\subsection{Results}

\subsubsection{PCR Results}

Amplification of 299 bp length fragment of the third exon (c960delG) of MSTN gene has 100\% positive results for 30 DNA samples, including 10 isolated from Selene breed cattle, 10 from Kazakh white head cattle and 10 from Mongolian cattle. Results of PCR for amplification of the third exon (c960delG) of MSTN gene of cattle were shown in Fig. 2.

\subsubsection{Sequencing Analysis}

The nucleotide sequences of MSTN gene from Mongolian breeds of cattle were sequenced and reported on the DDBJ/EMBL/GenBank database with a following accession numbers: Selenge cattle-LC142726, Kazakh white headed cattle—LC146648 and Mongolian cattle—LC146649.

\subsection{Discussion}

The nucleotides of the third exon of MSTN gene of Selenge, white head and Mongolian cattle were 99\%-100\% identity with prevoiusly registered sequences at DDBJ/EMBL/GenBank database with accession numbers JQ711180, EF422556, AB232692, AY850105,

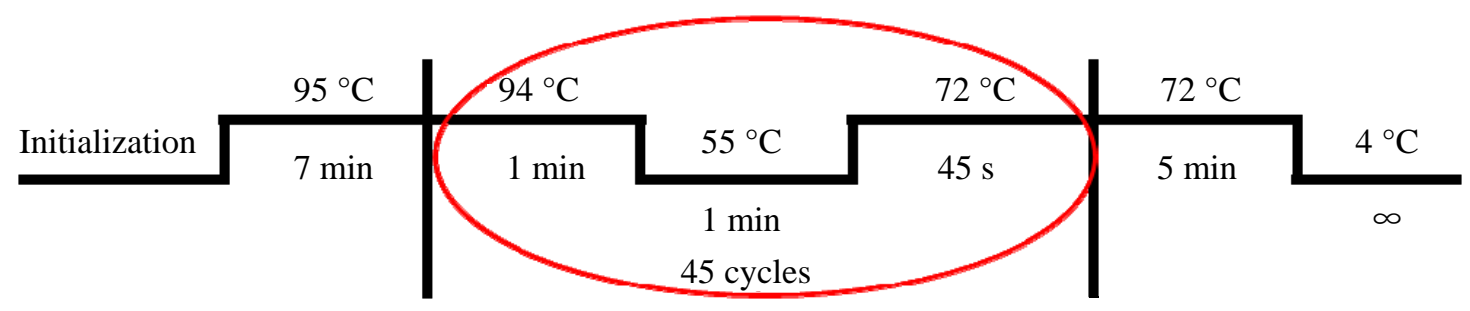

Fig. 1 Thermal cycling of amplification. 


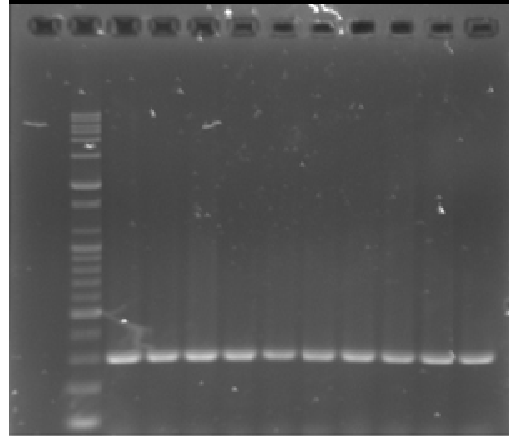

(a) 10 white headed Kazakh cattle

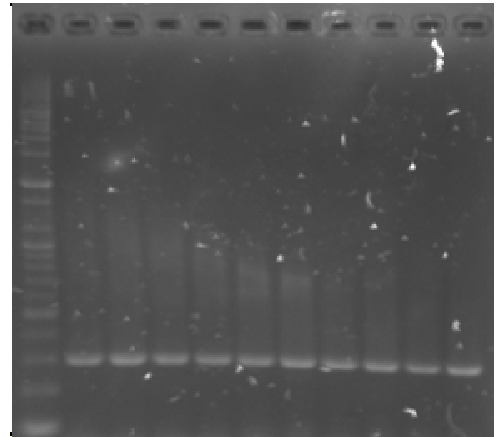

(b) 10 Selenge cattle

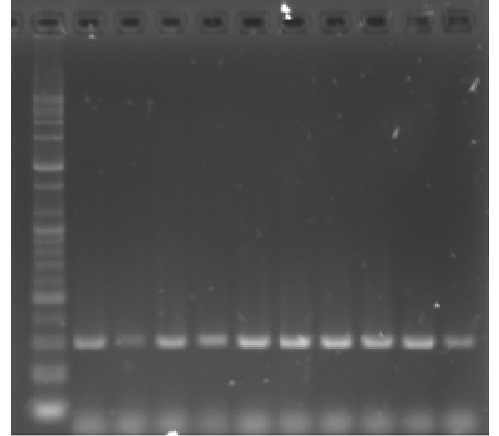

(c) 10 Mongolian cattle

Fig. 2 PCR results of the third exon fragment of MSTN gene.

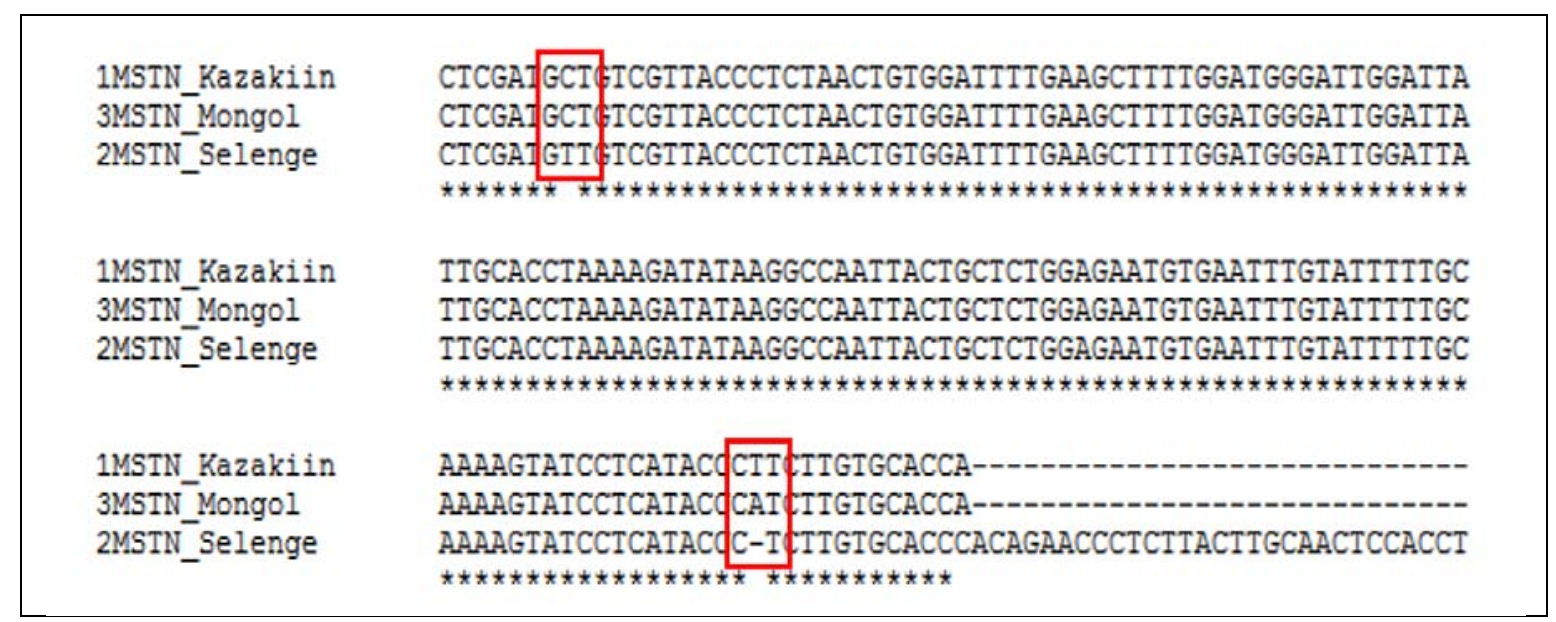

Fig. 3 Sequence alignment analysis of myostatin gene in cattle breeds.

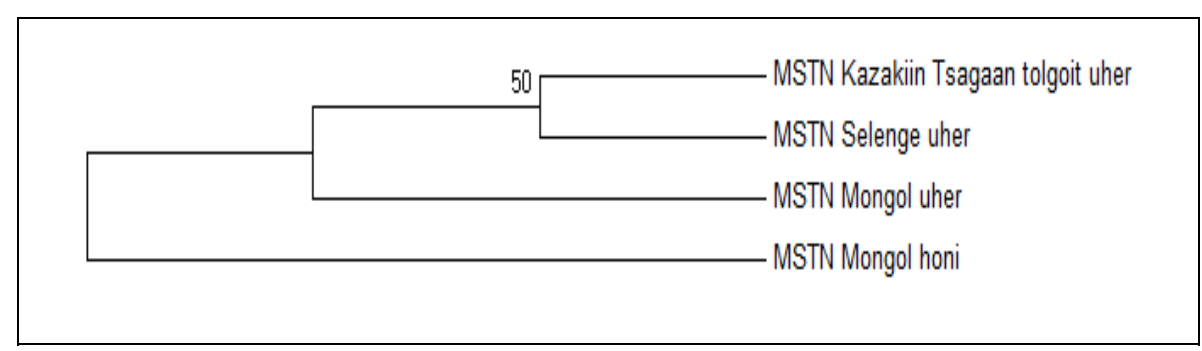

Fig. 4 Results of sequencing analysis.

JQ184147, AY160688, AF019620 of Colombia, Pianniu, Japanese black, Beefmaster, Chinese Bohai black, Korean native and Belgian blue.

As a result of comparing variable region of MSTN gene, the 450th nucleotide of Selenge cattle was different, and there was a gap at the 560th position of white headed Kazakh cattle. One nucleotide was detected different in Selenge cattle, causing change in the 283rd amino acid, and it was detected during the translation by Clustal W (1.83) and MEGA (4.0) (Fig. 3).
Origin of Mongolian cattle is different from both of Selenge and Kazakh breeds. But origin of Kazakh is closer to Selenge breed. Thus, Selenge cattle has the same origin with Kazakh which was initially used for breeding Selenge cattle. But Mongolian cattle was independently originated earlier than them during the evolution (Fig. 4).

A single nucleotide difference was detected in the third exon of MSTN of Selenge breed, meaning that there was a single nucleotide mutation in third exon of the MSTN gene (c960delG). The following studies 
provide several examples of phenotypic variations due to single nucleotide difference in $M S T N$ gene.

Double-muscling phenotype is an abundant for beef cattle, and this characteristic is caused by muscle hyperplasia and hypertrophy process, which is the result of reduction of intramuscular fat. And the final phenotype displays an increase of muscle mass [8].

The studies on myostatin protein which controlled by GDF-8 gene indicated that the improper regulation of this protein resulted double-muscling phenotype in some cattle breeds [13].

Belgian blue breed is double-muscled and the MSTN gene is located on the second chromosome of this cattle [13]. The double-muscling phenotype in Belgian blue breed was resulted by the 11th nucleotide deletion in the third exon of GDF-8 gene [20, 21], and in other double-muscled breeds, such as Piedmontese, the study suggested that the single nucleotide mutation in encoding part of MSTN gene caused that particular phenotype [9].

The single nucleotide change was detected in 5'promotor region of MSTN gene in Marchigiana breed, and the muscle mass index was 25\% higher than conventional cattle [14].

The results in this study gave the similar results with above-mentioned studies that the MSTN gene accounts for muscle development. And in this study, it is demonstrated that the mutation in the third exon part of MSTN gene in Selenge breed caused phenotype which considered as meat cattle trait.

However, due to the lack of analytical procedures for determining the presence of in deep genetic analysis of breeds of cattle, it should be continued for further.

\section{Conclusions}

MSTN gene from Mongolian breeds of cattle was sequenced and reported on the DDBJ/EMBL/GenBank database with a following accession numbers: Selenge breed-LC142726, Kazakh white head cattle—LC146648, Mongolian cattle—LC146649.
In terms of MSTN gene function, a mutation in third exon of MSTN gene in Selenge breed indicated genetic difference compared to other two breeds in Mongolia.

In order to better understand and reveal the correlation of MSTN gene function and phenotype traits and potential productivity of Selenge cattle, the further wide range study on this breed and other local breeds should be conducted.

\section{Acknowledgments}

The authors would like to acknowledge Dr. Erdenebileg Uyangaa (Institute of Veterinary Medicine, Mongolia), who is post-doctoral student of Chonbuck National University in Republic of Korea.

\section{References}

[1] Rothschild, M., and Soller, M. 1997. "Candidate Gene Analysis to Detect Genes Controlling Traits of Economic Importance in Domestic Livestock.” Probe Newslett. Agric. Genomics 8: 13-20.

[2] Undarmaa, B., Altangerel, D., and Lkhagvasuren, S. 2014. "GDF-8 Gene Study of Meat Sheep and Cattle." Agricultural Science Bulletin 12: 11-4. (in Mongolian)

[3] Fontanesi, L., Tazzoli, M., Scotti, E., and Russo, V. 2008. "Analysis of Candidate Genes for Meat Production Traits in Domestic Rabbit Breeds." In Proceedins of the 9th World Rabbit Congress, 79-82.

[4] Lee, S. J. 2004. "Regulation of Muscle Mass by Myostatin.” Ann. Rev. Cell Dev. Biol. 20: 61-86.

[5] Langley, B., Thomas, M., Bishop, A., Sharma, M., Gilmour, S., and Kambadur, R. 2002. "Myostatin Inhibits Myoblast Differentiation by Down-Regulating $M y o D$ Expression.” J. Biol. Chem. 277: 49831-40.

[6] Thomas, M., Langley, B., Berry, C., Sharma, M., Kirk, S., Bass, J., and Kambadur, R. 2000. "Myostatin, a Negative Regulator of Muscle Growth, Functions by Inhibiting Myoblast Proliferation.” J. Biol. Chem. 275 (51): 40235-43.

[7] Lines, D. S., Pitchford, W. S., Kruk, Z. A., and Bottema, C. D. 2009. "Limousin Myostatin F94L Variant Affects Semitendinosus Tenderness.” Meat Sci. 81 (1): 126-31.

[8] Wiener, P., Woolliams, J. A., Frank-Lawale, A., Ryan, M., Richardson, R. I., Nute, G. R., Wood, J. D., Homer, D., and Williams, J. L. 2009. "The Effects of a Mutation in the Myostatin Gene on Meat and Carcass Quality.” Meat Sci. 83: 127-34.

[9] Grisolia, A. B., D’Angelo, G. T., Porto Neto, L. R., Siqueira, F., and Garcia, J. F. 2009. "Myostatin (GDF8) 
Single Nucleotide Polymorphisms in Nellore Cattle.” Genet. Mol. Res. 8: 822-30.

[10] Esmailizadeh, A. K., Bottema, C. D., Sellick, G. S., Verbyla, A. P., Morris, C. A., Cullen, N. G., and Pitchford, W. S. 2008. "Effects of the Myostatin F94L Substitution on Beef Traits.” J. Anim. Sci. 86 (6): 1038-46.

[11] Grobet, L., Pirottin, D., Farnir, F., Poncelet, D., Royo, L. J., Brouwers, B., Christians, E., Desmecht, D., Coignoul, F., Kahn, R., and Georges, M. 2003. "Modulating Skeletal Muscle Mass by Postnatal, Muscle Specific Inactivation of the Myostatin Gene.” Genesis 35 (4): 227-38.

[12] Tang, L., Yan, Z., Wan, Y., Han, W., and Zhang, Y. 2007. "Myostatin DNA Vaccine Increases Skeletal Muscle Mass and Endurance in Mice.” Muscle Nerve. 36 (3): 342-8.

[13] Johnson, P. L., McEwan, J. C., Dodds, K. G., Purchas, R. W., and Blair, H. T. 2005. "A Directed Search in the Region of GDF8 for Quantitative Trait Loci Affecting Carcass Traits in Texel Sheep.” J. Anim. Sci. 83 (9): 1988-2000.

[14] Marchitelli, C., Savarese, M. C., Crisa, A., Nardone, A., Marsan, P. A., and Valentini, A. 2003. "Double Muscling in Marchigiana Beef Breed Is Caused by a Stop Codon in the Third Exon of Myostatin Gene.” Mamm. Genome 14 (6): 392-5.

[15] Joulia-Ekaza, D., and Cabello, G. 2006. "Myostatin
Regulation of Muscle Development: Molecular Basis, Natural Mutations, Physiopathological Aspects.” Experimental Cell Research 312 (13): 2401-14.

[16] Boman, I. A., Klemetsdal, G., Blichfeldt, T., Nafstad, O., and Vage, D. I. 2009. "A Frameshift Mutation in the Coding Region of the Myostatin Gene (MSTN) Affects Carcass Conformation and Fatness in Norwegian White Sheep (Ovis aries).” Animal Genetics 40 (4): 418-22.

[17] Elkorshy, N., Mahrous, K. F., and Salem, L. M. 2013. "Genetic Polymorphism Detection in Four Genes in Egyptian and Saudi Sheep Breeds.” World Applied Sciences Journal 27 (1): 33-43.

[18] Benson, D. A., Karsch-Mizrachi, I., Lipman, D. J., Ostell, J., Rapp, B. A., and Wheeler, D. L. 2002. "GenBank." Nucleic Acids Res. 30 (1): 17-20.

[19] Altschul, S. F., Gish, W., Miller, W., Myers, E. W., and Lipman, D. J. 1990. "Basic Local Alignment Search Tool.” J. Mol. Biol. 215 (3): 403-10.

[20] Kambadur, R., Sharma, M., Smith, T. P. L., and Bass, J. J. 1997. "Mutations in Myostatin (GDF8) in Double-Muscled Belgian Blue and Piedmontese Cattle.” Genome Res. 7: 910-5.

[21] Casas, E., Keele, J. W., Shackelford, S. D., Koohmaraie, M., Sonstegard, T. S., Smith, T. P. L., Kappes, S. M., and Stone, R. T. 1998. "Association of the Muscle Hypertrophy Locus with Carcass Traits in Beef Cattle.” $J$. Anim. Sci. 76 (2): 468-73. 